\title{
PENGARUH KOMPENSASI TERHADAP KINERJA KARYAWAN \\ PADA PT. SRI METRIKO UTAMA WIDJAJA PALEMBANG
}

\author{
Dita Aryani \\ Mahasiswa Perbankan Syariah STEBIS IGM Palembang \\ Email: ditaaryani@yahoo.com \\ Meriyati \\ Dosen Perbankan Syariah STEBIS IGM Palembang \\ Email : meri@stebisigm.ac.id,
}

\begin{abstract}
ABSTRAK
Pesatnya perkembangan perusahaan pada saat ini mendorong setiap perusahaan untuk dapat bersaing secara sehat dan mempertahankan usahanya dengan baik. Semakin suatu perusahaan berkembang maka akan semakin banyak karyawan yang berkualitas agar dapat mengolah sumber daya perusahaan yang ada dengan menggunakan peralatan perusahaan sebagai alat bantu pengolahan. Penempatan karyawan yang tepat sesuai dengan bidangnya sangat mempengaruhi kinerja didalam perusahaan dan mengurangi kesalahan yang tidak diinginkan. Banyaknya karyawan yang berkualitas diharapkan mampu mencapai tujuan utama perusahaan yaitu memperoleh laba yang optimal. Laba yang diperoleh oleh perusahaan dapat menjadikan tolak ukur sejauh mana kemampuan yang telah dicapai perusahaan. Laba yang diperoleh perusahaan diharapkan dapat didistribusikan untuk kelangsungan hidup perusahaan dan mensejahterakan para karyawan dengan memberikan gaji dan upah yang sesuai dengan kinerjanya. Salah satu faktor yang mempengaruhi tingkat keberhasilan suatu perusahaan adalah kinerja karyawan. Kinerja karyawan adalah hasil kerja secara kualitas dan kuantitas yang dicapai oleh seseorang karyawan dalam melaksanakan tugasnya sesuai dengan tanggung jawab yang diberikan kepadanya.
\end{abstract}

Kata Kunci: Kompensasi, Kinerja Karyawan.

\section{DASAR PEMIKIRAN}

Pada awal PT Sri Metriko Utamawidjaja didirikan oleh Yayasan kesejahteraan karyawan PUPUK SRIWIJAYA (YKKP), PT Sri Metriko Utamawidjaja yang beralamat di Jl Mayor Zen Palembang merupakan sebuah perusahaan yang bergerak dibidang service dan supply peralatan mekanikal, elektrikal instrumen, elektronik, komunikasi dan navigasi dan menjadi perusahaan swasta nasional terdepan disektor Jasa Mekanikal, Elektrikal, Konstruksi dan Distribusi. Memberikan kesejahteraan kepada share holder dan stake holder serta karyawan melalui komitmen terhadap tata kelola perusahaan yang baik. 
84 | Dita Aryani. Pengaruh Kompensasi Terhadap Kinerja Karyawan pada PT. Sri Metriko...

Mulai tahun 2013 PT Sri Metriko Utamawidjaja ini mempercayakan jabatan direktur kepada Arman Z, ST, SH, MH, CFE, QIA, CLA yang bertugas sebagai pemimpin perusahaan dan juga mempunyai dewan pembina yang sekaligus merangkap menjadi pemegang saham bagi PT Sri Metriko Utamawidjaja.

PT Sri Metriko Utamawidjaja ini mempunyai jajaran direksi Arif Priatomo, SE sebagai Manager Adm \& Keuangan dan Manager Teknik \& Operasi dipimpin oleh Ir. Pasmah Ramli sedangkan yang memimpin Manager Pemasaran adalah Mulud Sutrasman para jajaran direksi ini diberikan amanat untuk menuduki jabatan pada tahun 2013 hingga sekarang. (Dokumentasi: Bagian Personalia, tanggal 23 Februari 2018).

Laba yang diperoleh oleh perusahaan dapat menjadikan tolak ukur sejauh mana kemampuan yang telah dicapai perusahaan. Laba yang diperoleh perusahaan diharapkan dapat didistribusikan untuk kelangsungan hidup perusahaan dan mensejahterakan para karyawan dengan memberikan gaji dan upah yang sesuai dengan kinerjanya. Penempatan karyawan yang tepat sesuai dengan bidangnya sangat mempengaruhi kinerja didalam perusahaan dan mengurangi kesalahan yang tidak diinginkan. Banyaknya karyawan yang berkualitas diharapkan mampu mencapai tujuan utama perusahaan yaitu memperoleh laba yang optimal. Allah memerintahkan manusia bekerja sebagai salah satu bentuk nyata manusia dalam rangka memakmurkan bumi seperti firman Allah dalam ayat berikut:

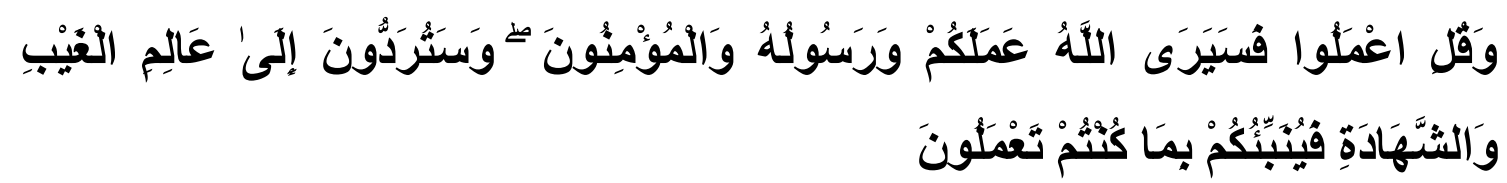

Artinya: Dan katakanlah,” Bekerjalah kamu, maka Allah akan melihat pekerjaanmu, begitu juga Rasul-Nya dan orang-orang mukmin, dan kamu akan dikembalikan kepada (Allah) yang mengetahui yang gaib dan yang nyata, lalu diberitakan-Nya kepada kamu apa yang telah kamu kerjakan (QS. At-Taubah 9:105).

Tafsiran ayat ini menurut Quraish Shihab: adalah katakan kepada manusia, "Bekerjalah kalian dan jangan segan-segan melakukan perbuatan baik dan melaksanakan kewajiban. Sesungguhnya Allah mengetahui segala pekerjaan kalian, dan Rasulullah serta orang-orang mukmin akan melihatnya. Mereka akan menimbangnya dengan timbangan keimanan dan bersaksi dengan perbuatan-perbuatan itu. Kemudian setelah mati, kalian akan dikembalikan kepada Yang Maha Mengetahui lahir dan batin 
kalian, lalu mengganjar dengan perbuatan-perbuatan kalian setelah dia memberitahu kalian segala hal yang kecil dan besar dari perbuatan kalian itu. (Sihab, 2009).

Allah berfirman dalam melakukan suatu pekerjaan serta akan mendapatkan balasan untuk mereka terdapat dalam ayat berikut:

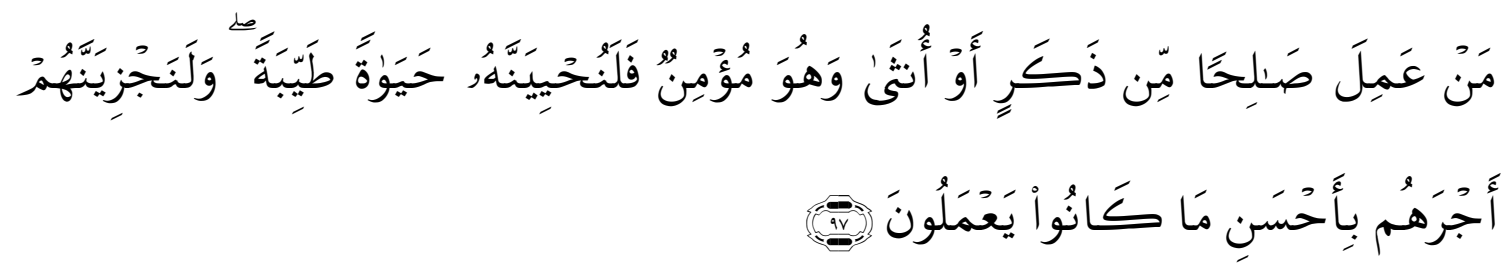

Artinya: "Barang siapa mengerjakan kebajikan, baik laki-laki maupun perempuan dalam keadaan beriman, maka pasti akan kami berikan kehidupan kepadanya kehidupan yang baik dan kami akan beri balasan dengan pahala yang lebih baik dengan apa yang telah mereka kerjakan. (QS. An-Nahl 16:97).

Salah satu faktor yang mempengaruhi tingkat keberhasilan suatu perusahaan adalah kinerja karyawan. Kinerja karyawan adalah hasil kerja secara kualitas dan kuantitas yang dicapai oleh seseorang karyawan dalam melaksanakan tugasnya sesuai dengan tanggung jawab yang diberikan kepadanya (Mangkunegara, 2013:67). Suatu sistem imbalan atau kompensasi yang baik adalah sistem yang mampu menjamin kepuasan para anggota perusahaan yang pada gilirannya memungkinkan perusahaan memperoleh, memelihara dan mempekerjakan sejumlah orang yang dengan berbagai sikap dan perilaku bekerja dengan produktif bagi kepentingan perusahaan (Sondang, 2013:253).

Kompensasi adalah semua pendapatan yang berbentuk uang, barang langsung atau tidak langsung yang diterima karyawan sebagai imbalan atas jasa yang diberikan kepada perusahaan (Hasibuan, 2008:118). Sedangkan menurut Sutrisno (2011:184). Pada dasarnya kompensasi itu dapat dibagi menjadi dua aspek, yaitu kompensasi langsung dan tidak langsung. Kompensasi langsung adalah kompensasi yang diberikan langsung berhubungan dengan hasil kerja karyawan yang bersangkutan. Adapun kompensasi tidak langsung, maksudnya yaitu pemberian kompensasi tidak dikaitkan dengan hasil kerja karyawan yang bersangkutan.

Karyawan menuntut gaji yang mencukupi kebutuhannya dan keluarganya dalam bertahan hidup ditengah mahalnya harga-harga kebutuhan pokok dan kenaikan inflasi. 
86 | Dita Aryani. Pengaruh Kompensasi Terhadap Kinerja Karyawan pada PT. Sri Metriko...

Namun di sisi lain, perusahaan pun menginginkan efisiensi dalam merekrut dan membayar para pekerjanya. Kontradiksi inilah seringkali menimbulkan friksi antara para pekerja dan perusahaan. Oleh karena itu, pemberian upah yang adil dan proporsional sangat krusial dalam kehidupan perusahaan agar tercipta hubungan yang saling menguntungkan dan win win solution antara karyawan dan perusahaan. Sebagaimana diriwayatkan dalam hadist Ibnu Majjah berikut:

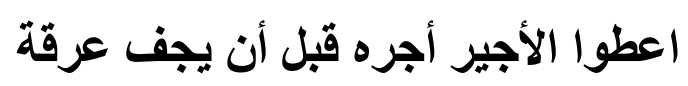

Artinya: “ berikan kepada seseorang pekerja sebelum keringatnya kering." (HR. Ibnu Majjah).

PT. Sri Metriko Utamawidjaja yang lebih dikenal dengan nama PT. SMU bergerak dibidang Jasa yaitu sebagai service and supply. Masalah yang timbul pada PT. Sri Metriko Utamawidjaja peneliti menemukan adanya kinerja karyawan sekarang ini mengalami banyak kemajuan yang pesat dalam memberikan pelayanan kepada para pelanggannya. Dan yang menyebabkan kemajuan pesat terhadap kinerja karyawan adalah pengaruh kompensasi yang diberikan kepada karyawan tersebut baik yang bersifat langsung maupun tidak langsung, karena kompensasi yang diberikan sebanding dengan kinerja karyawan tersebut.

\section{PEMBAHASAN}

\section{Pengertian Kompensasi}

Setiap perusahaan pasti memiliki tujuan, peranan penting dari sistem pengendalian manajemen adalah memotivasi para anggota perusahaan untuk mencapai tujuan perusahaan. Salah satu caranya dengan memberikan para anggota perusahaan kompensasi atau insentif kepada mereka. Kompensasi merupakan elemen hubungan kerja yang sering menimbulkan masalah dalam hubungan industri. Masalah kompensasi, khususnya upah, selalu menjadi perhatian manajemen organisasi, karyawan dan pemerintah (Zamzam dan Aravik, 2017: 198). Kompensasi dimaknai sebagai semua pendapatan yang berbentuk uang, barang, langsung atau tidak langsung yang diterima karyawan sebagai imbalan atas jasa yang diberikan kepada perusahaan. (Hasibuan, 2008:118) Sedangkan menurut Zainal (2009:541) kompensasi merupakan sesuatu yang diterima karyawan sebagai pengganti 
kontribusi jasa mereka pada perusahaan. Pemberian kompensasi merupakan salah satu pelaksanaan fungsi MSDM yang berhubungan dengan semua jenis pemberian penghargaan individula sebagai pertukaran dalam melakukan tugas keorganisasian.

\section{Jenis-Jenis Kompensasi}

Banyak pendapat yang menyatakan tentang jenis-jenis kompensasi yang diterima oleh karyawan. Salah satunya menurut Zainal (2013:741) kompensasi terbagi menjadi dua yaitu sebagai berikut:

a. Kompensasi Finansial:

Kompensasi finansial terdiri atas dua yaitu kompensasi langsung dan kompensasi tidak langsung (tunjangan):

b. Kompensasi finansial langsung

Terdiri atas pembayaran pokok (gaji, upah), pembayaran prestasi, pembayaran insentif, komisi, bonus, bagian keuntungan, opsi saham, sedangkan pembayaran tertanggung meliputi tabungan hari tua, saham komulatif.

c. Kompensasi finansial tidak langsung

Terdiri atas proteksi yang meliputi asuransi, pesangon, sekolah anak, pensiun. Kompensasi luar jam kerja meliputi lembur, hari besar, cuti sakit, cuti hamil, sedangkan berdasarkan fasilitas meliputi rumah, biaya pindah dan kendaraan.

d. Kompensasi non finansial

Kompensasi non finansial terdiri atas karir yang meliputi aman pada jabatan, peluang promosi, pengakuan karya, temuan baru, prestasi istimewa, sedangkan lingkungan kerja meliputi dapat pujian, bersahabat, nyaman bertugas, menyenangkan dan kondusif.

e. Pada dasarnya dikelompokkan kedalam dua kelompok, yaitu kompensasi finansial dan kompensasi bukan finansial. Selanjutnya kompensasi finansial ada yang langsung dan tidak langsung. Sedangkan finansial nonfinansial dapat berupa pekerjaan dan lingkungan pekerjaan. Menurut Panggabean (2010:80) mengumukakan bahwa:

1. Kompensasi keuangan langsung terdiri atas:

a. Gaji : Gaji adalah imbalan finansial yang dibayarkan kepada karyawan secara teratur, seperti tahunan, caturwulan, bulanan atau mingguan. Gaji merupakan jenis penghargaan yang paling penting dalam organisasi 
88 | Dita Aryani. Pengaruh Kompensasi Terhadap Kinerja Karyawan pada PT. Sri Metriko...

b. Upah: Upah merupakan imbalan finansial langsung dibayarkan kepada pera pekerja berdasarkan jam kerja, jumlah barang yang dihasilkan atau banyaknya pelayanan yang diberikan. Jadi tidak seperti gaji yang jumlahnya relatif tetap, besarnya upah dapat berubah-ubah. Pada dasarnya gaji atau upah diberikan untuk menarik calon pegawai agar mau masuk menjadi karyawan.

c. Insentif: Insentif merupakan imbalan langsung yang dibayarkan kepada karyawan karena kinerjanya melebihi standar yang ditentukan. Dengan mengasumsikan bahwa uang dapat digunakan untuk mendorong karyawan bekerja lebih giat lagi, maka mereka yang produktif lebih menyukai gajinya dibayarkan berdasarkan hasil kerja. Untuk itu diperlukan kemampuan untuk menentukan standar yang tepat. Tidak terlalu mudah untuk dicapai dan juga tidak terlalu sulit. Standar yang terlalu mudah tentunya tidak menguntungkan bagi perusahaan. Sedangkan yang terlalu sulit menyebabkan karyawan frustasi.

2. Kompensasi tidak langsung (Fringe benefit)

Fringe benefit merupakan kompensasi tambahan yang diberikan berdasarkan kebijakan perusahaan terhadap semua karyawan dalam usaha meningkatkan kesejahteraan karyawan. Contohnya asuransi kesehatan, asuransi jiwa, dan bantuan perumahan dan menurut Dessler (2009:62) kompensasi mempunyai tiga komponen sebagai berikut:

a. Pembayaran uang secara langsung (direct financial payment) dalam bentuk gaji, dan intensif atau bonus/komisi.

b. Pembayaran tidak langsung (indirect payment) dalam bentuk tunjangan dan asuransi.

c. Ganjaran non finansial (non financial rewards) seperti jam kerja yang luwes dan kantor yang bergengsi.

d. Tujuan Kompensasi

Dalam sebuah organisasi setiap kegiatan pasti memiliki tujuan guna mencapai tujuan dari perusahaan, seperti hal nya dalam pemberian kompensasi. Tujuan pemberian kompensasi menurut Hasibuan (2008:225-226) sebagai berikut:

e. Ikatan kerja sama

Dengan pemberian kompensasi terjalinlah ikatan kerja sama formal antara majikan dengan karyawan. Karyawan harus mengerjakan tugas-tugasnya 
dengan baik, sedangkan pengusaha/majikan wajib membayar kompensasi sesuai dengan perjanjian yang disepakati.

f. Kepuasan kerja

Dengan balas jasa, karyawan akan dapat memenuhi kebutuhan-kebutuhan fisik, status sosial dan egoistiknya sehingga memperoleh kepuasan kerja dari jabatannya.

3. Pengadaan efektif

Jika program kompensasi ditetapkan cukup besar, pengadaan karyawan yang qualified untuk perusahaan akan lebih mudah.

4. Motivasi

Jika balas jasa yang diberikan cukup besar, manajer akan mudah memotivasi karyawannya.

\section{Deskripsi Karakteristik Responden}

Penyajian deskriptif data penelitian bertujuan agara dapat melihat profil dari data penelitian tersebut yang behubungan antar variabel dalam penelitian. Data deskriptif responden yang menggambarkan keadaan dan kondisi responden merupakan informasi tambahan untuk memahami hasil- hasil penelitian. Karakteristik responden dalam penelitian ini peneliti bagi menjadi lima karakter, yakni : berdasarkan jenis kelamin, Usia, pendidikan terakhir, lama bekerja, besaran gaji. Deskripsi mengenai karakteristik responden penelitian penelitian jabarkan pada subbab dibawah ini:

1. Jenis Kelamin

Data yang mengenai jenis kelamin responden dikelompokkan menjadi dua yaitu jenis kelamin Wanita dan Pria. Data menjadi dua yaitu berhasil dikumpulkan dari penelitian mengenai jenis kelamin karyawan PT. SMU yang berkenan menjadi responden menjadi responden adalah sebagai berikut:

Tabel 4.1 Jenis Kelamin Responden

JenisKelamin

\begin{tabular}{|c|c|c|c|c|}
\hline & Frequency & Percent & $\begin{array}{c}\text { Valid } \\
\text { Percent }\end{array}$ & $\begin{array}{c}\text { Cumulative } \\
\text { Percent }\end{array}$ \\
\hline $\mathrm{V}$ & 73 & 74.5 & 74.5 & 74.5 \\
\hline
\end{tabular}




\begin{tabular}{|r|r|r|r|r|r|}
\hline Pria & 20 & 20.4 & 20.4 & 94.9 \\
\cline { 2 - 6 } & Wanita & 5 & 5.1 & 5.1 & 100.0 \\
\hline Total & 98 & 100.0 & 100.0 & \\
\hline
\end{tabular}

Sumber: Data primer diolah, 2018

Dari tabel diatas, dapat mengetahui jenis kelamin responden PT. SMU yang bersedia menjadi responden. Data diatas menujukkan bahwa responden dengan jenis kelamin Wanita 5,1 \% dan responden dengan jenis kelamin Pria 20,4\% .

2. Usia Responden

Data mengenai usia responden disini, penelitian mengelompokkan menjadi empat kategori yaitu responden yang berusia 20-30 tahun, 31-40 tahun, 41-50 tahun, dan responden yang berumur $>50$ tahun. Adapun data yang berhasil diperoleh dari peneliti mengenai usia karyawan PT. SMU yang berkenan menjadi responden adalah sebagai berikut:

Tabel 4.2 Usia Responden

Usia

\begin{tabular}{|c|c|c|c|c|c|}
\hline & & Frequency & Percent & $\begin{array}{c}\text { Valid } \\
\text { Percent }\end{array}$ & $\begin{array}{c}\text { Cumulative } \\
\text { Percent }\end{array}$ \\
\hline \multirow[t]{6}{*}{ V } & & 73 & 74.5 & 74.5 & 74.5 \\
\hline & $>50$ & 5 & 5.1 & 5.1 & 79.6 \\
\hline & $20-30$ & 5 & 5.1 & 5.1 & 84.7 \\
\hline & $31-40$ & 3 & 3.1 & 3.1 & 87.8 \\
\hline & $41-50$ & 12 & 12.2 & 12.2 & 100.0 \\
\hline & Total & 98 & 100.0 & 100.0 & \\
\hline
\end{tabular}

Sumber: Data primer diolah, 2018.

Dari tabel diatas, dapat mengetahui usia responden karyawan PT. SMU. Data tersebut menunjukkan bahwa responden dengan umur 20-30 tahun sebesar 5,1\%, 
responden dengan umur 31-40 tahun sebesar 3,1\%, responden dengan umur 41-50 tahun sebesar 12,2 \%, dan responden dengan umur $>50$ tahun sebesar 5,1\%.

3. Pendidikan Terakhir Responden

Data mengenai pendidikan responden, disini peneliti mengelompokkan menjadi 4 yaitu: responden yang telah menempuh pendidikan SMP, SMA, Diploma, dan Sarjana. Adapun data yang behasil dikumpulkan dari peneliti mengenai pendidikan terakhir karyawan PT. SMU yang berkenan menjadi responden adalah sebagai berikut:

Tabel 4.3 Pendidikan Terakhir Responden

Pendidikan

\begin{tabular}{|c|c|c|c|c|c|}
\hline & & $\begin{array}{c}\text { Frequen } \\
\text { cy }\end{array}$ & Percent & $\begin{array}{c}\text { Valid } \\
\text { Perce } \\
\text { nt }\end{array}$ & $\begin{array}{r}\text { Cumulative } \\
\text { Percent }\end{array}$ \\
\hline \multirow[t]{5}{*}{ Val } & & 73 & 74.5 & 74.5 & 74.5 \\
\hline & DIPLOMA & 4 & 4.1 & 4.1 & 78.6 \\
\hline & SARJANA & 5 & 5.1 & 5.1 & 83.7 \\
\hline & SMA & 16 & 16.3 & 16.3 & 100.0 \\
\hline & Total & 98 & 100.0 & 100.0 & \\
\hline
\end{tabular}

Sumber: Data primer diolah, 2018.

Berdasarkan keterangan pada tabel diatas, dapat mengetahui tentang pendidikan terakhir karyawan PT. SMU yang diambil menjadi responden. Diketahui bahwa 16,3\% pendidikan terakhir responden berlatar belakang SMA, sedangkan 4,1 $\%$ pendidikan terakhir responden adalah Diploma, dan $5,1 \%$ pendidikan terakhir responden adalah Sarjana. Dari data diatas menunjukkan bahwa sebagian besar karyawan PT. SMU yang diambil adalah SMA.

4. Lama Bekerja Responden

Data mengenai lama bekerja responden, disini peneliti mengelompokkan menjadi 3 kategori yaitu 1-2 tahun, 2-3 tahun, dan $>4$ tahun. Adapun data yang 
92 | Dita Aryani. Pengaruh Kompensasi Terhadap Kinerja Karyawan pada PT. Sri Metriko...

berhasil peneliti kumpulkan mengenai lama bekerja karyawan PT. SMU yang berkenan menjadi responden adalah sebagai berikut:

Tabel 4.4 Lama Bekerja Responden

Lama bekerja

\begin{tabular}{|c|c|c|c|c|c|}
\hline & & $\begin{array}{c}\text { Frequen } \\
\text { cy }\end{array}$ & $\begin{array}{r}\text { Perce } \\
n t\end{array}$ & $\begin{array}{l}\text { Valid } \\
\text { Percent }\end{array}$ & $\begin{array}{r}\text { Cumulative } \\
\text { Percent }\end{array}$ \\
\hline \multirow[t]{5}{*}{ Val } & & 73 & 74.5 & 74.5 & 74.5 \\
\hline & $>4$ Tahun & 20 & 20.4 & 20.4 & 94.9 \\
\hline & 1-2 Tahun & 4 & 4.1 & 4.1 & 99.0 \\
\hline & 2-3 Tahun & 1 & 1.0 & 1.0 & 100.0 \\
\hline & Total & 98 & 100.0 & 100.0 & \\
\hline
\end{tabular}

Berdasarkan keterangan pada tabel diatas, dapat mengetahui tentang lama bekerja karyawan PT. SMU yang diambil menjadi responden. Diketahui bahwa lama bekerja responden 1-2 tahun sebesar 4,1\%, kemudian lama bekerja responden 2-3 tahun sebesar 1\%, dan lama bekerja responden $>4$ tahun sebesar 20,4\%.

5. Besaran Gaji Responden

Data mengenai besaran gaji responden, disini peneliti mengelompokkan menjadi 3 kategori yaitu responden dengan besaran gaji 1-2 juta, responden dengan besaran gaji 2-3 juta, dan responden dengan besaran gaji $>4$ juta. Adapun data yang berhasil dikumpulkan dari peneliti mengenai penghasilan karyawan PT. SMU yang berkenan menjadi responden adalah sebagai berikut:

Tabel 4.5 Besaran Gaji Responden

Besarangaji

\begin{tabular}{|r|r|r|r|c|}
\hline & Frequency & Percent & $\begin{array}{r}\text { Valid } \\
\text { Percent }\end{array}$ & Cumulative Percent \\
\cline { 1 - 4 } & 73 & 74.5 & 74.5 & 74.5 \\
\hline
\end{tabular}




\begin{tabular}{|r|r|r|r|r|}
\hline >3 Juta & 4 & 4.1 & 4.1 & 78.6 \\
\hline 1-2 Juta & 4 & 4.1 & 4.1 & 82.7 \\
\hline 2-3 Juta & 17 & 17.3 & 17.3 & 100.0 \\
\hline Total & 98 & 100.0 & 100.0 & \\
\hline
\end{tabular}

Dari tabel diatas, dapat mengetahui besaran gaji karyawan PT. SMU yang diambil sebagai responden. Data tersebut menunjukkan bahwa, responden dengan besaran gaji 1-2 juta sebanyak 4,1\%, sedangkan respondeng dengan besaran gaji 2-3 juta sebanyak 17,3\%, dan responden dengan besaran gaji > 3juta sebanyak 4,1\%.

\section{Sistem Kompensasi}

PT. Sri Metriko Utamawidjaja (SMU) memiliki peraturan dalam pemberian kompensasi yang memuat pedoman dalam perhitungan gaji, upah, dan insentif yang diberikan kepada karyawannya. Oleh karena itu, dalam memberikan kompensasi terhadap karyawan bagian akuntansi dan umum yang bertugas dalam melakukan pemberian kompensasi harus melihat kriteria kerja karyawan sesuai atau tidaknya dengan kebijakan yang dibuat dan diberlakukan pada sistem kompensasi tersebut.

Sistem kompensasi pada PT. SMU diawali dengan dibuatnya surat pernyataan kesediaan, sebelum karyawan memulai bekerja mereka harus menandatangani kontrak kerja yang berkaitan dengan kejelasan pekerjaannya dari mulai karyawan melakukan training sampai dengan perekrutan sebagai karyawan tetap. Surat Keputusan ini juga memuat lampiran gaji yang akan diterima oleh karyawan. PT. SMU menetapkan gaji pokok tergantung pada jabatan dan masa kerja karyawannya. Maksudnya gaji yang diberikan berdasarkan UMP (Upah Minimum Provinsi), kemudian dari gaji pokok tersebut ditambahkan dengan berbagai bonus/komisi yang penentuan besarnya bonus itu didasarkan atas masa kerja dan berdasarkan jabatan karyawan. PT. SMU mempunyai kebijakan lain seperti apabila ternyata ada karyawan yang tidak masuk kerja tanpa ada alasan jelas, maka konsekuensinya karyawan tersebut akan mendapatkan potongan gaji.

Tunjangan, yang penentuan besarnya tunjangan itu didasarkan atas masa kerja dan berdasarkan jabatan karyawannya. Mengenai kinerja karyawan di PT. Sri Metriko Utamawidjaja dari hasil penelitian dapat diuraikan bahwa kinerja karyawan dilihat dari 
94 | Dita Aryani. Pengaruh Kompensasi Terhadap Kinerja Karyawan pada PT. Sri Metriko...

penyelesaian kerja seperti melakukan pelayanan yang cepat saat sedang dalam mengerjakan perbaikan atau service selesai dengan waktu yang ditentukan dan sudah sesuai dengan kuantitas yang ditetapkan, tanggung jawab seperti melakukan penyelesaian tugas yang diberikan berdasarkan kualitas kerja yang baik, tingkat kedisiplinan seperti selalu hadir tepat waktu dalam bekerja dan diusahakan tidak mangkir tanpa alasan yang tidak jelas, efektivitas dalam pekerjaan seperti menunjukkan peningkatan keterampilan dan pengetahuan yang baik dalam berkerja seperti saat seperti 1 tahun sekali dilakukannya pelatihan kepada karyawan sesuai dengan kebijakan, serta dapat berperan aktif dalam lingkungan kerja.

Hal ini menunjukkan bahwa kinerja karyawan baik secara kualitas dan kuantitas di PT. Sri Metriko Utamawidjaja (SMU). Untuk mengetahui apakah terdapat pengaruh yang signifikan antara kompensasi terhadap kinerja karyawan, maka peneliti membagikan kuisioner kepada setiap karyawan di PT. SMU.

Dari hasil penyajian data yang dilakukan terbukti bahwa nilai signifikansi variabel kompensasi sebesar 0,000 dan 0,000 lebih kecil dari $\alpha=0,05$, sedangkan besar koefisien variabel kompensasi sebesar 0,911. Dan t hitung sebesar 5,243 lebih besar dari t tabel sebesar 1,708, maka Ho ditolak dan Ha diterima. Besarnya koefisien determinasi yang disesuaikan $\mathrm{R}$ square adalah sebesar 0,544 artinya 54,4\% variabel kinerja karyawan (Y) dapat dijelaskan oleh variabel kompensasi. Sedangkan sisanya yaitu 45,6\% (100\%-54,4\%) dijelaskan oleh variabel lain yang tidak diketahui dan tidak termasuk dalam penelitian ini. Maka dengan ini dapat disimpulkan bahwa kompensasi berpengaruh secara signifikan terhadap kinerja karyawan. Artinya semakin tinggi kompensasi yang diberikan terhadap karyawan maka semakin tinggi pula tingkat kualitas kinerja karyawan.

\section{SIMPULAN}

Dari berbagai penjelasan di atas dapat disimpulkan sebagai berikut:

1. Dari hasil penelitian yang dilakukan berdasarkan analisis data yang diperoleh bahwa kompensasi memiliki pengaruh terhadap kinerja karyawan pada PT. Sri Metriko Utamawidjaja. Hal ini ditunjukkan dengan nilai signifikansi variabel kompensasi sebesar 0,000 dan 0,000 lebih kecil dari $\alpha=0,05$, sedangkan besar koefisien variabel kompensasi sebesar 0,911. Dan t hitung sebesar 5,243 lebih besar dari t tabel sebesar 
1,708, maka Ho ditolak dan Ha diterima. Besarnya koefisien determinasi yang disesuaikan $\mathrm{R}$ square adalah sebesar 0,544 artinya 54,4\% variabel kinerja karyawan (Y) dapat dijelaskan oleh variabel kompensasi. Sedangkan sisanya yaitu 45,6\% (100\%-54,4\%) dijelaskan oleh variabel lain yang tidak diketahui dan tidak termasuk dalam penelitian ini.

2. Pengaruh tersebut diindikasikan dari pemberian balas jasa yang adil, sehingga timbul adanya kinerja karyawan yang akan memberikan dampak positif juga terhadap PT. SMU. Dan nantinya akan menimbulkan hubungan kerja sama yang saling membutuhkan dan menguntungkan antara PT. SMU serta karyawan.

\section{Saran}

1. Berdasarkan hasil penelitian yang telah disajikan, maka selanjutnya peneliti menyampaikan saran-saran yang dapat memberikan manfaat kepada pihak-pihak yang terkait atas hasil penelitian ini. Adapun saran-saran yang dapat disimpulkan peneliti adalah sebagai berikut.

2. Berdasarkan hasil penelitian yang dilakukan, maka yang dapat dilakukan oleh PT. Sri Metriko Utamawidjaja dalam pemberian kompensasi terhadap karyawannya harus mempertimbangkan pengalaman, pendidikan, tanggung jawab pekerjaan serta mengkonfirmasikan terlebih dahulu dengan karyawan agar tidak terjadi kesalahpahaman antara karyawan dengan perusahaan sehingga tidak ada pihak yang dirugikan.

\section{DAFTAR PUSTAKA}

Dessler, Gary. (2009). Manajemen Sumber Daya Manusia. Jakarta: PT. Indeks.

Hasibuhan, Malayu S.P. (2003). Manajemen Sumber Daya Manusia. Edisi Revisi. Jakarta: PT. Bumi Aks

Mangkunegara, Anwar Prabu. (2013). Manajemen Sumber Daya Manusia. Bandung: Remaja Rosdakarya.

Panggabean, Mutiara.S. (2004). Manajemen Sumber Daya Manusia. Bogor: Ghalia Indonesia.

Sihab, Qurais. 2009. Tafsir Al-Misbah, Pesan, Kesan dan Kerasian al-Qur'an. Jakarta: Lentera Hati. 
96 | Dita Aryani. Pengaruh Kompensasi Terhadap Kinerja Karyawan pada PT. Sri Metriko...

Sondang Paian Siagian, 2013. Mengembalikan Kepercayaan Publik Melalui Reformasi Birokrasi. Lembaga Administrasi Negara

Sutrisno, Edy. (2009). Manajemen Sumber Daya Manusia. Jakarta: Prenadamedia Group.

Zainal, Veithzal Rivai, Dkk. (2009). Manajemen Sumber Daya Manusia Untuk Perusahaan: Dari Teori ke Praktik. Jakarta: Raja Grafindo Persada.

.. (2013). Manajemen Sumber Daya Manusia Untuk Perusahaan: Dari Teori ke Praktik. Jakarta: Raja Grafindo Persada.

Zamzam, Fakhry, dan Havis Aravik, 2017. Manajemen SDM Berbasis Syariah, Bogor: CV. RWTC Success. 